\title{
TINGKAH LAKU SOSIAL RUSA TIMOR (Cervus timorensis) DI PENANGKARAN BUMI MARINA, MANOKWARI.
}

\section{SOCIAL BEHAVIOR OF DEER TIMOR (Cervus timorensis) IN CAPTIVITY BUMI MARINA, MANOKWARI}

Jerianto Tawala Madja ${ }^{1}$, Johan F. Koibur ${ }^{2}$, Freddy Pattiselanno ${ }^{2}$

${ }^{1}$ Alumni Program Studi Peternakan, Jurusan Peternakan, Fakultas Peternakan, ${ }^{2}$ Sub-Laboratorium Aneka Ternak dan Satwa, Fakultas Peternakan Universitas Papua

ABSTRAK

Article history

Accepted: May 4, 2018 ;

Approved: June 1, 2018

* Corresponding author:

E-mail:

jeriantomadja93@gmail.com, mananwirkoibur@gmail.com f.pattiselanno@unipa.ac.id
Deer is a wild animal that has economi value and can be utilized by the commnity as a source of protein of animal origin so that the deer can be breed by the communty. In papua deer have been cultivated or breed in a relativery large scare. The purpose of cultivation or captivity is to know the daily behavior or deer timor (Cervus timorensis) in brooder breeding condtion with large numbers of pet populations. The time of study for \pm one month is from the beginning of september to the and of september 2017. Using 10 sample from 24 deer in breeding, 3 aduit males, 2 young males, 3 adult females and 1 young females and 1 culf. Using time observation method with observation technique. Analyze data using exel to find the percen tage of social activity from each time period. Each time period was divided into I 06:00-08:00(6,48\%); II 08:00-10:00(25,93\%); III 10:0012:00(19,44\%); IV 12:00-14:00(7,41\%); V 14:00-16:00(6,48) and VI 16:0018:00 $(34,26)$. Our findings showed that social activity/interaction in group much more observed in the afternoon.

Key words: behavior, social, Timor deer, captivity

\section{PENDAHULUAN}

Rusa Timor (Cervus timorensis) adalah salah satu spesies asli Indonesia yang dapat ditangkarkan (Siregar et al., 1984). Hal mana didukung oleh beberapa kajian yang kemudian dilakukan dan menunjukan adanya harapan terhadap pemanfaatan rusa sebagai hewan ternak (Badarina, 1995; Subekti, 1995; Dradjat, 1996 dan Pattiselanno, 2003). Beberapa factor pendukung usaha pengembangan rusa sebagai hewan ternak yaitu karena rusa mempunyai kemampuan adaptasi yang tinggi, demikian juga pakan dan air bukanlah merupakan faktor pembatas. Rusa dapat mengkonsumsi hampir semua jenis dedaunan dan rumput, tahan terhadap kekurangan air sehingga rusa mampu menyesuaikan dengan kondisi agroekosistem yang beragam (Naipospos, 2003). Kondisi ini didukung pula dengan diterbitkannya SK Menteri No. 362/Kpts/TN.102/5/1990 yang menyatakan bahwa rusa ditetapkan sebagai hewan yang dapat diternakkan.

Tingkah laku sosial adalah merupakan upaya yang harus di pahami dan dimengerti oleh peternak sehigga dapat meningkatkan pembudidayaan ternak .Usaha mengembangkan penangkaran rusa skala besar mulai diusahakan dengan pemeliharaan hewan peliharaan mencapai sekitar 20an ekor. Dalam pengamatan pendahuluan yang dilakukan, di usaha penangkaran rusa di Bumi Marina, penanganan hewan peliharaan masih terkendala tingkah laku akibat peralihan dari kebiasaan hidup liar di alam ke dalam suasana penangkaran yang ada. Guna perbaikan penanganan hewan peliharaan dalam suasana penangkaran maka pengamatan terhadap tingkah laku sosial rusa peliharaan menjadi sangat penting sebagai dasar pengelolaan usaha penangkaran yang sudah ada saat ini. 
Rusa merupakan hewan liar yang memiliki nilai ekonomis dan dapat dimanfaatkan oleh masyarakat sebagai sumber protein asal hewani. Namun menurut Undang Undang no. 134 dan 260 tahun 1931 rusa adalah binatang liar yang dilindungi dan pada tahun 1990 Rusa telah masuk sebagai hewan ternak baru berdasarkan SK Menteri Pertanian no. 362/KPS/TN (Semiadi 1995). Di Papua rusa sudah dibudidayakan atau ditangkarkan dalam skala yang kecil (1-3 ekor) dengan cara diikat.

Peralihan tempat hidup bebas di alam ke dalam suasana penangakaran dengan ruang gerak yang terbatas memerlukan pendekatan baik, benar dan memenuhi syarat penanganan hewan ternak. Oleh karena itu penelitian ini dilakukan untuk mengkaji tingkah laku sosial untuk pengembangan usaha peternakan ini secara serius di waktu mendatang.

Tujuan dari penelitian ini adalah untuk mengetahui tingkah laku harian rusa Timor (Cervus timorensis) dalam kondisi penangkaran yang lebih luas dengan jumlah populasi hewan peliharaan yang relatif banyak.

Hasil penelitian ini diharapkan dapat menjadi pedoman atau pengetahuan dasar bagi pengelola penangkaran yang kemudian dapat disebar luaskan bagi masyarakat dan pihakpihak terkait sebagai upaya mendukung pengembangan penangkaran rusa yang lebih baik.

\section{MATERI DAN METODE}

Penelitian berlangsung yaitu dari tanggal 14-30 September 2017, di penangkaran rusa timor ARO-M milik dr. Frans di Bumi Marina, Kelurahan Amban. .

\section{Materi}

Bahan penelitian adalah rusa timor yang berada di penangkaran. Sedangkan alat yang digunakan adalah : kamera video, kamera digital untuk mengambil gambar sebagai dokumentasi, Jam tangan /stopwatch sebagai penunjuk waktu, counter, dan alat tulis menulis.

\section{Metode}

Penelitian dilakukan menggunakan metode 'Time sampling' (Martin dan Bateson 1986) dengan teknik pengamatan (observasi) langsung dilapangan.

Teknik penelitian dilakukan langsung dilapangan terhadap tingkah laku harian seperti kegiatan sosial di penangkaran. Pengamatan akan dilakukan pada siang hari yaitu dari pukul 06:00 sampai dengan pukul 18:00 WIB dan dibagi ke dalam enam periode waktu pengamatan pukul 06:00-08:00; 08:0010:00; 10:00-12:00; 12:00-14:00; 14:00-16:00 dan 16:00-18:00 WIB, semua kegiatann rusa dicacat.

Data yang akan dikumpulkan dalam penelitian ini adalah data primer dan data sekunder. Data primer adalah data mengenai perilaku harian rusa timor (Cervus timorensis) yang diperoleh dari pengamatan langsung dengan metode Time sampling (Martin dan Bateson 1986). Pada setiap periode waktu pengamatan Dengan metode ini akan dilakukan pencatatan terhadap perilaku rusa setiap 20 menit. Sedangkang data sekunder adalah data yang diperlukan sebagai data penunjang dari data primer yang akan diperoleh melalui studi literatur mengenai penangkaran, perilaku, dan faktor-faktor lain yang menunjang keberhasilan dalam kegiatan penangkaran rusa timor.

Perilaku yang akan diamati adalah : Perilaku sosial, yaitu intreraksi antara rusa dalam satu kelompok.

\section{Analisis Data}

Data dan informasi hasil pengamatan dianalisis secara deskriptif dan kuantitatif. Analisis deskriptif digunakan untuk mendeskripsikan kegiatan sosial. Analisis kuantitatif digunakan untuk mengetahui persentase perilaku yang dapat dihitung dengan menggunakan rumus sebagai berikut :

\section{Presentase waktu seluruh perilaku $(\%)=\frac{A}{B} x 100 \%$}

Keterangan:

$\mathrm{A}=$ waktu yang digunakan untuk suatu perilaku dalam satu hari pengamatan

$\mathrm{B}=$ Jumlah waktu dalam satu hari. 


\section{HASIL DAN PEMBAHASAN}

\section{Keadaan Umum}

Luasan area penangkaran Rusa Timor ARO-M adalah $126 \mathrm{~m}$ x $96 \mathrm{~m}$, yang terletak di area pemukiman Kelurahan Amban, Distrik Manokwari Barat, Kabupaten Manokwari,
Papua Barat. Dalam area penangkaran tersebut hanya terdapat sebuah tempat bernaungan pada rusa dengan luasan 25 meter x 5 meter, dan terdapat rumput lapangan yang dapat dikonsumsi oleh rusa tersebut.

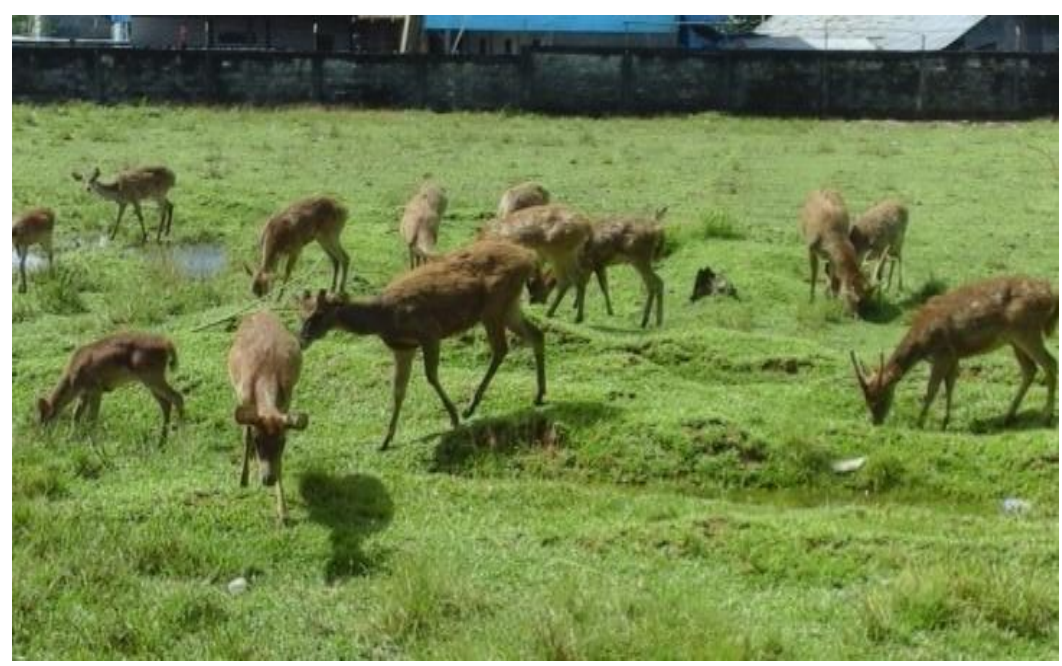

Gambar 1 : Area Penangkaran Bumi Marina

Dalam area penangkaran tersebut terdapat 24 ekor ternak rusa yang di pemelihara secara ekstensif yaitu dengan cara melepas rusa dalam area penangkaran. Pakan diperoleh dari rumput yang ada di area penangkaran seperti rumput karpet, teki dan jarum. Pengamatan tingkah laku rusa dilakukan dari pukul 06:00 pagi sampai dengan 18:00 di sore hari.

\section{Aktivitas Sosial/interaksi dalam kelompok}

Tabel 1: Aktivitas sosial Rusa Timor dalam penangkaran

\section{Frekuensi (x)/Periode Waktu}

\begin{tabular}{lcccccccc} 
Tingkah Laku & \multicolumn{1}{c}{ 06:00- } & $08: 00-$ & $10: 00-$ & $12: 00-$ & $14: 00-$ & $16: 00-$ & Total & Rataan (\%) \\
& $08: 00$ & $10: 00$ & $12: 00$ & $14: 00$ & $16: 00$ & $18: 00$ & & \\
\hline Sosial & 7 & 28 & 21 & 8 & 7 & 37 & 108 & 100,00 \\
Rataan \% & 6,48 & 25,93 & 19,44 & 7,41 & 6,48 & 34,26 & 100,00 & \\
\hline
\end{tabular}

Dari hasil pengamatan rusa dewasa lebih banyak interaksi dalam kelompok di bandingkan rusa muda dan rusa kecil jarang sekali melakukan adanya interaksi dalam kelompok. Hal ini sama dengan yang dilaporkan oleh Wirdateti et al (2005) bahwa rusa sangat sensitif dengan keadaan, bila terjadi perubahan atau gangguan rusa dewasa lebih tanggap dan memberikan isyarat kepada yang lain.
Aktivitas sosial adalah perilaku yang dilakukan dengan cara saling berinteraksi antar kelompok. Hubungan sosial lebih banyak di perlihatkan oleh induk dan anak dan juga pejantanpejantan yang ada, pejantan akan terus bermain baik sesudah maupun belum merumput, mereka akan beradu tanduk sama yang lain. Sifat sosial pejantan jarang sekali di perlihatkan untuk betina. 
Hal ini terjadi kemungkinan karena belum musim kawin.

Menurut Schroder (1976), Rusa timor umumnya berkembang biak pada bulan Juni sampai September dan masa buntingnya sekitar sembilan bulan. Rusa betina mencapai dewasa kelamin pada umur 7-9 bulan. Umur berkembang biak pertama (Minimun breeding age) adalah 1518 bulan dan Maksimum breeding age 15-18 tahun. Lama menyusui anak rusa adalah 2-3 bulan dan paling lambat 5 bulan, sedangkan lama kebuntingan Rusa timor adalah 8-9 bulan dan jumlah rusa yang dilahirkan terdiri dari 1-2 ekor namun pada umumnya satu ekor. Musim kawin ini akan menghambat produktivitas rusa timor.

Jika musim kawin rusa jantan akan terus mendekati betina, untuk mendapatkan betina, rusa akan bersaing atau berkelahi dengan rusa jantan lain sampai muncul salah satu pemenang dan ini akan berlangsung 2-3 jam tergantung banyaknya saingan (Wirdateti et al 2005).

Aktivitas sosial pada rusa dapat di perlihatkan sepanjang hari yaitu dari pagi sampai dengan sore hari dan tertinggi pada pukul 16:00-18:00 WIT, ini terjadi diduga karna pada periode waktu tersebut rusa sudah mau beristrahat dan sehingga lebih banyak bermain. Tetapi pada periode waktu 06:0008:00 WIT ini terjadi karna di pagi hari rusa lebih banyak merumput karna di pagi hari rumput belum mengalami evavorasi dan periode waktu 14:0016:00 rendah karna periode ini sushu sangat panas sehingga rusa banyak berbaring di bawa naungan untuk melakukan memabiak aktifitas rusa dapat dilihat pada tabel 1 .

\section{PENUTUP}

\section{Kesimpulan}

Dari penelitian ini dapat disimpulkan bahwa :

1. Perilaku sosial pada rusa timor lebih banyak dilakukan oleh Rusa betina dewasa terhadap anaknya dan rusa jantan dewasa terhadap rusa betina dan sesama rusa jantan dewasa.

2. Rusa muda dan rusa anakan kurang memperlihatkan interaksinya dalam kelompok.

\section{DAFTAR PUSTAKA}

Badarina, 1. 1995. Rusa "satwa harapan" sumber protein hewani masa depan. Ruminansia, IX(4), 7-8.

Dradjat, A.S., 1996. Potensi rusa sebagai hewan unggulan di Kawasan Timur Indonesia. Lokakarya pengembangan Peternakan Terpadu dengan Intensifikasi Tinggi di Kawasan Timur Indonesia, Mataram
Duwila, 2001. Sistem pemeliharaan dan ukuran statistik vital Rusa Timor (Cervus timorensis) di Kabupaten Manokwari. Skripsi Fakultas Peternakan. Universitas Negeri Papua, Manokwari.

Martin dan Bateson. 1986. Measuring Behaviour: An Introductory Guide.Cambridge University Press London

Naipospos, T.S.P., 2003. Rencana strategis dalam pemanfaatan rusa sebagai usaha aneka ternak. Lokakarya Pengembangan Rusa Taman Mini Indonesia Inda

Pattiselanno, F. Ansius 1sir, D. Takege A. dan Seseray, D. 2008. Kajian Awal Penangkaran Rusa Timor (Cervus timorensis) Sistem Back Yard di Manokwari, Papua Barat. Biosfera 25 (2): 95-100

Pattiselanno, F. 2003. Deer (Cervidae:Artiodactyla:Mammalia) wildlife potential with future expectations. Tigerpaper, 30(3), 13-16

Semiadi G. 1995. Tatalaksana pemeliharaan Rusa Timorensis (Cervus timorensis) oleh Masyarakat di Pulau Timor. Puslitbang Biologi LIPI Bogor.

Semiadi, G. Dan Nugraha, R. T. P. 2004. Panduan Pemeliharaan Rusa Tropis. Puslit Biologi LIPI. Bogor

Siregar, A.P., Sitorus, P, Radjagukguk, PA., ${ }^{\wedge}$ Santoso, Sabrani, M., Soedirman, S', iskandar, T., Kalsid, E., balubira, L.P., Sitohang, H., Syarifuddin, A., Saleh, A,, dan Wiloto., 1g84. Kemungkinan budidaya satwa liar di Indonesia. Proceeding Seminar Satwa Liar. Pusat Penelitian dan Pengembangan Peternakan, Bogor.

Subekti, D.T., 1995. Mengenal usaha peternakan rusa. Ruminansia, IX(3), 34-35.

Takandjandji M dan M. Sinaga. 1995. Perilaku rusa timor (Cervus timorensis) di penangkaran. Balai Litbang Kehutanan Kupang

Tekandjanji M, Gersetiasih R. 2002. Pengembangan Penangkaran Rusa Timor (Cervus timorensis) dan permasalahannya di Nusa Tenggara Timur. Prosiding Seminar Nasional Bioekologi dan Konservasi Ungulata. Pusat Studi Ilmu Hayati, Lembaga Penelitian IPB pusat Penelitian Biologi LIPI dan Pengembangan Hutan dan Konservasi Alam Denput. Bogor

Thohari M. A, Masyud B, Takanjanji M (2011). Seminar Sehari Prospek Penangkaran Rusa Timor (Cervus timorensis) Sebagai Stok Perburuan. Fakultas Kehutanan IPB. Bogor

Thohari et al. 1991. Studi kelayakan dan perancangan tapak penangkaran rusa di 
BKPH Jonggol, KPH Bogor. Perum Perhutani Unit III Jawa Barat.

Wanma, D.F. 2008. Tingkah Laku Harian Rusa Timor Jantan (Cervus timorensis) Yang Dipelihara Oleh Masyarakat Di Kota Manokwari. Skripsi Fakultas Peternakan. Universitas Negeri Papua..
Wirdateti, Mansur M, dan Kundarmasno A (2005). Pengamatan Tingkah laku Rusa Timor (Cervus timorensis) di PT Kuala Tembaga, Desa Aertembaga, Bitung- Sulawesi Utara. Puslit Biologi-LIPI Bogor 2005 